\title{
Effects of ocean acidification on the immune response of the blue mussel Mytilus edulis
}

\author{
Ruth Bibby ${ }^{1,2}$, Steve Widdicombe ${ }^{1, *}$, Helen Parry ${ }^{1}$, John Spicer $^{2}{ }^{2}$ Richard Pipe ${ }^{3}$ \\ ${ }^{1}$ Plymouth Marine Laboratory, Prospect Place, West Hoe, Plymouth PL1 3DH, UK \\ ${ }^{2}$ Marine Biology and Ecology Research Centre, University of Plymouth, Plymouth PL4 8AA, UK \\ ${ }^{3}$ The Marine Biological Association, Citadel Hill, The Hoe, Plymouth PL1 2PB, UK
}

\begin{abstract}
The effects of medium term (32 d) hypercapnia on the immune response of Mytilus edulis were investigated in mussels exposed to acidified (using $\mathrm{CO}_{2}$ ) sea water $(\mathrm{pH} 7.7,7.5$ or 6.7; control: $\mathrm{pH}$ 7.8). Levels of phagocytosis increased significantly during the exposure period, suggesting an immune response induced by the experimental set-up. However, this induced stress response was suppressed when mussels were exposed to acidified sea water. Acidified sea water did not have any significant effects on other immuno-surveillance parameters measured (superoxide anion production, total and differential cell counts). These results suggest that ocean acidification may impact the physiological condition and functionality of the haemocytes and could have a significant effect on cellular signalling pathways, particularly those pathways that rely on specific concentrations of calcium, and so may be disrupted by calcium carbonate shell dissolution.
\end{abstract}

KEY WORDS: Mytilus edulis - Ocean acidification - Carbon capture and storage · Seawater pH · Immune response $\cdot$ Phagocytosis

\section{INTRODUCTION}

Pre-industrial (ca. 1750) atmospheric $\mathrm{CO}_{2}$ levels were approximately $280 \mathrm{ppm}$, whilst present day atmospheric $\mathrm{CO}_{2}$ levels have increased to over $380 \mathrm{ppm}$ (Feely et al. 2004), primarily as a result of anthropogenic activities. This increase would have been greater, were it not for the fact that almost one half of the anthropogenically produced $\mathrm{CO}_{2}$ has been taken up by the oceans. Whilst this has slowed the rate of global warming (Sabine et al. 2004), a negative consequence is ocean acidification. Ocean $\mathrm{pH}$ has declined by 0.1 unit, compared with pre-industrial values (Orr et al. 2005), and is predicted to decrease a further 0.4 units by the end of the 21st century, and possibly by $0.7 \mathrm{pH}$ units by 2250 (Caldeira \& Wickett 2003). The net effect of the dissolution of $\mathrm{CO}_{2}$ in sea water is to increase the concentration of hydrogen ions (lowering pH), and of carbonic acid and bicarbonate ions, while decreasing the concentration of carbonate ions (Raven et al. 2005). The reduction in available carbonate ions is likely to have biological implications for marine biota that require carbonate minerals to form their shells or skeletons (Caldeira \& Wickett 2003, Feely et al. 2004). However, the concurrent decrease in the $\mathrm{pH}$ of sea water may also have biological, physiological and evolutionary consequences for all forms of marine biota at many different organisational levels.

Mitigation strategies to reduce atmospheric $\mathrm{CO}_{2}$ levels are well developed and their potential is globally recognised (Widdicombe \& Needham 2007). One such method involves injecting $\mathrm{CO}_{2}$ into underground porous reservoir rocks (Holloway 2005). However, sub-seabed storage leaks are possible over time (Hawkins 2004). These leaks could cause severe local reductions in $\mathrm{pH}$, affecting offshore organisms, habitats and marine processes. Impacts could also occur inshore, as $\mathrm{CO}_{2}$ would be transported from landbased capture plants to offshore storage sites via subseabed pipes. Again, leakage from these pipes is possible. Consequently, research which investigates major $\mathrm{pH}$ decreases is required to understand the effects that $\mathrm{CO}_{2}$ leakage may have on the marine environment. 
Exposure to acidified sea water disrupts growth and development in a number of pelagic and intertidal organisms (Riebesell et al. 2000, Ishimatsu et al. 2004, Kikkawa et al. 2004, Pörtner et al. 2004, Bibby et al. 2007). One group which has received particular attention with respect to acidification and climate change is marine mussels (Michaelidis et al. 2005, Berge et al. 2006, Gazeau et al. 2007, Petes et al. 2007). This is because they are important ecosystem engineers, and, like all calcifying organisms, they are vulnerable to ocean acidification. Their byssus threads enhance sediment stability and provide a habitat for smaller invertebrates or 'cryptic fauna'. Mussels are also an important food source for other organisms, including birds and humans (Nagarajan et al. 2006).

Michaelidis et al. (2005) found that seawater $\mathrm{pH}<7.5$ was harmful to shelled molluscs, causing permanent reductions in haemolymph $\mathrm{pH}$, growth and metabolism, and increased haemolymph bicarbonate levels derived from shell dissolution. Berge et al. (2006) also found that acidification negatively affected mussel growth and suggested that this is related to metabolic depression. Gazeau et al. (2007) showed that calcification rates in Mytilus edulis declined linearly with increasing $\mathrm{CO}_{2}$ levels, juveniles being particularly sensitive to acidification. Even with a recent increase in $\mathrm{CO}_{2}$ research, the overall effects of elevated oceanic $\mathrm{CO}_{2}$ on organisms and ecosystems are still poorly known and unpredictable, especially regarding the sensitivity of $\mathrm{CO}_{2}$ on defence functions.

The internal defence system of invertebrates is based on an innate, non-lymphoid immune system (Wootton \& Pipe 2003) involving effective methods for cellular recognition and for discriminating foreign cells and harmful micro-organisms (Renwrantz 1990). The predominant mechanism of internal defence in bivalves involves phagocytosis by circulating haemocytes, followed by the release of reactive oxygen metabolites and degradative enzymes, and secretion of cytotoxic molecules (Pipe \& Coles 1995). Bivalve haemocytes are also involved in nutrient digestion and transport, wound and shell repair, and excretion (Cheng 1981). Thus, any dysfunction in the immune system may have consequences for the nervous and endocrine systems (Koller 1990). Despite the importance of this form of defence, nothing is known of the effect of acidification on immune function.

Consequently, we conducted a medium-term, i.e. $32 \mathrm{~d}$, mesocosm experiment to investigate the effect of exposure to acidified sea water on key aspects of the immune response of Mytilus edulis. Mussels were exposed to $\mathrm{pH}$ levels mimicking ocean acidification ( $\mathrm{pH} 7.7$ or 7.5 ) or a leakage from a sub-seabed $\mathrm{CO}_{2}$ storage site ( $\mathrm{pH}$ 6.7). A multi-assay approach was used to obtain an overall view of immune competence in mussels under acidification stress.

\section{MATERIALS AND METHODS}

Study organisms. On June 17, 2007, Mytilus edulis (40 to $50 \mathrm{~mm}$ shell length) were collected by hand from Trebarwith Strand, North Cornwall, England $\left(50^{\circ} 38^{\prime} 40.97^{\prime \prime} \mathrm{N}, 4^{\circ} 45^{\prime} 41.78^{\prime \prime} \mathrm{W}\right)$ and transported to a mesocosm at Plymouth Marine Laboratory (PML) within $3 \mathrm{~h}$ of sampling. All individuals were cleaned of epibionts, such as barnacles and algae, using a metal scraper. Mussels were then placed in a large (50 l) aerated seawater storage tank $\left(18.6^{\circ} \mathrm{C}, \mathrm{pH} 8.01\right.$, salinity 33.3). The mussels were kept in this tank overnight (12 h), during which time they were not fed.

Experimental set-up. Experimentation commenced the next day and lasted for $32 \mathrm{~d}_{;} 4$ covered header tanks (450 l) were each filled with sea water $\left(15^{\circ} \mathrm{C}\right.$, salinity 34$)$ taken from the PML storage tank $\left(16 \mathrm{~m}^{3}\right)$, which is itself supplied periodically with deep water collected approximately $14 \mathrm{~km}$ offshore. Using the control system described in Widdicombe \& Needham (2007), each of the header tanks was set to maintain seawater through the addition of $\mathrm{CO}_{2}$ gas at 1 of $4 \mathrm{pH}$ levels: 7.8 (ambient seawater), 7.7, 7.5 and 6.7. Each header tank supplied 2 duplicate exposure tanks (50 l) containing mussels ( $\mathrm{n}=50$ in each tank). Header tank $\mathrm{pH}$ was monitored using flat surface, combination $\mathrm{pH}$ electrodes (Walchem S650CD), calibrated using NIST standardised buffers prior to experimentation, and $\mathrm{CO}_{2}$ addition was regulated by a computerised feedback relay system (Walchem WebMaster-GI controller USA). Acidified seawater from the header tanks was continuously supplied by grav-

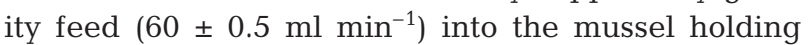
tanks. Natural sea water ( $\mathrm{pH} 7.92)$ replaced the water within the header tanks, thus increasing seawater $\mathrm{pH}$ and triggering the addition of $\mathrm{CO}_{2}$ until the $\mathrm{pH}$ had reached its pre-set level (Table 1) (Widdicombe \& Needham 2007).

Overflow water from each exposure tank was allowed to run off, creating a flow-through system preventing build up of metabolic wastes. $\mathrm{pH}$ and $\mathrm{pCO}_{2}$ within all tanks were monitored every $24 \mathrm{~h}$ using a calibrated $\mathrm{pH}$ meter (Mettler Toledo InLab $413 \mathrm{SG}$ ) and $\mathrm{pCO}_{2}$ probe (Jenco $\mathrm{mV}$ meter 6230). pH in the exposure tanks was maintained around the target $\mathrm{pH}$ (Table 1); wide $\mathrm{pH}$ ranges occurred, because on rare occasions the holding tanks experienced short-term deviations from the target $\mathrm{pH}$ when a $\mathrm{CO}_{2}$ cylinder became empty (resulting in higher $\mathrm{pH}$ ) or due to leaks in the $\mathrm{CO}_{2}$ supply system (resulting in a lower $\mathrm{pH}$ ). These were quickly remedied, and deviations only lasted for a few hours; we think that they had little or no effect on our findings. Temperature and salinity were measured every $24 \mathrm{~h}$ using a Tetra Con 325 salinity and temperature probe. During the experiment, mussels were fed with a 
Table 1. Seawater $\mathrm{pH}, \mathrm{pCO}_{2}$ and temperature (mean $\pm 95 \% \mathrm{CI}, \mathrm{pH}$ range in parentheses) in mussel holding tanks

\begin{tabular}{|c|c|c|c|c|}
\hline $\begin{array}{l}\text { Treat- } \\
\text { ment }\end{array}$ & $\begin{array}{l}-\mathrm{pH} \\
\text { Measured }\end{array}$ & $\begin{array}{l}\overline{\text { Concentration }} \\
\text { (ppm) }\end{array}$ & $\begin{array}{l}\mathrm{CO}_{2} \\
\text { Partial pressure } \\
(\mathrm{Pa})\end{array}$ & $\begin{array}{l}\text { Tempera- } \\
\text { ture } \\
\left({ }^{\circ} \mathrm{C}\right)\end{array}$ \\
\hline 7.9 & $7.83 \pm 0.03(7.6$ to 8.0$)$ & $665.7 \pm 1.5$ & $65.3 \pm 1.4$ & $17.24 \pm 0.77$ \\
\hline 7.7 & $7.65 \pm 0.04(7.2$ to 7.9$)$ & $1160.7 \pm 2.1$ & $114.1 \pm 2.1$ & $16.25 \pm 0.52$ \\
\hline 7.4 & $7.49 \pm 0.04(7.1$ to 7.7$)$ & $1435.2 \pm 1.4$ & $140.8 \pm 1.3$ & $16.61 \pm 0.48$ \\
\hline 6.5 & $6.70 \pm 0.09(6.2$ to 7.0$)$ & $3316.2 \pm 2.5$ & $325.1 \pm 2.4$ & $16.95 \pm 0.46$ \\
\hline
\end{tabular}

solution of live Pavlova spp. (30 mg dry mass mussel ${ }^{-1}$ day $\left.^{-1}\right)$, diluted in sea water and supplied to each mussel holding tank by a peristaltic pump (1 $\mathrm{ml} \mathrm{min}^{-1}$; Watson Marlow 2058).

Sampling regime. Sampling took place on Days 0, 2, 4, 8, 16 and 32. On each sampling occasion, 16 mussels were randomly selected from each treatment, and haemolymph was taken from each individual as described below. Samples from 10 mussels were used for the analysis of immune function and the remaining 6 samples were analysed for cell counts. During the experiment, each mussel was only sampled once.

Immunological assays. Haemolymph $(0.5 \mathrm{ml})$ was extracted using a $2.5 \mathrm{ml}$ syringe, the needle (21 gauge) of which was carefully inserted into the large sinus within the posterior adductor muscle. Samples for immune assays were withdrawn into an equal volume of $0.1 \mathrm{M}$ Tris- $\mathrm{HCl}$ buffer (TBS), pH 7.6, containing $2 \%$ $\mathrm{NaCl}$. Samples for total and differential cell counts were fixed with an equal volume of Baker's formolcalcium fixative ( $4 \%$ formaldehyde, $2 \% \mathrm{NaCl}, 1 \%$ calcium acetate) (Wootton \& Pipe 2003).

Phagocytosis assay: Aliquots $(50 \mu \mathrm{l})$ of each sample were pipetted into 4 replicate microplate wells with an equal volume of neutral red stained, heat stabilised zymosan (Sigma) (Parry \& Pipe 2004). Zymosan and TBS buffer were used as controls. Haemocytes fixed with zymosan were used as blanks. After incubation and a series of cleaning steps (details in Pipe et al. 1995), haemocytes were solubilised in $0.1 \mathrm{ml}$ of a mixture of acetic acid (1\%) and ethanol (50\%), and incubated for $30 \mathrm{~min}$ at $30^{\circ} \mathrm{C}$ to solubilise the neutral red from the phagocytosed zymosan particles. Plates were then read using a SpectraMax microplate reader (Molecular Devices) at $\lambda=550 \mathrm{~nm}$.

Reduction of nitroblue tetrazolium (NBT assay): The NBT assay estimates the intracellular production of superoxide dismutase (SOD) inhibitable reactive oxygen metabolites produced by mussel haemocytes (Parry \& Pipe 2004). Aliquots of haemolymph in TBS were pipetted into 6 microplate wells. NBT $\left(2 \mathrm{mg} \mathrm{ml}^{-1}\right)$ in TBS $(0.1 \mathrm{ml})$ was added to 3 of the replicate wells per sample, and NBT containing SOD from bovine ery- throcytes (activity $=300$ units $\mathrm{ml}^{-1}$ ) was added to the remaining 3 wells; 3 further replicate wells containing $0.1 \mathrm{ml}$ NBT solution and $0.1 \mathrm{ml}$ TBS acted as blank controls for each plate. The foilcovered plates were incubated at $10^{\circ} \mathrm{C}$ for 30 min after which they were centrifuged at $120 \times g$ for $10 \mathrm{~min}$. After a series of washing steps (described in Pipe et al. 1995) all samples were dissolved in dimethyl sulphoxide (DMSO) $(0.14 \mathrm{ml})$ (Sigma) and $\mathrm{KOH}(0.12 \mathrm{ml}$, $2 \mathrm{~mol} \mathrm{l}^{-1}$ ). The plates were read on the microplate reader at $\lambda=620 \mathrm{~nm}$.

Protein content analysis: To express results of the immune assays as optical density per unit of haemocyte protein, the protein content of the haemolymph was measured using a protein assay kit (bicinchoninic acid, BCA; Pierce). Haemolymph samples (50 $\mu \mathrm{l})$ from each mussel used in the previous assays were digested in an equal volume of $1 \%, 3$-([3-cholamidopropyl]-dimethylammonio)-1-proanesulfonate (CHAPS) solution (Pierce) for $30 \mathrm{~min}$ at $30^{\circ} \mathrm{C}$. Sub-samples of this mixture $(10 \mu \mathrm{l})$ were placed into 3 replicate wells, and a standard calibration curve was constructed using bovine serum albumin standards. BCA $(0.2 \mathrm{ml})$ reagent was added to each well and blanks with TBS were created. Plates were incubated for $30 \mathrm{~min}$ at $30^{\circ} \mathrm{C}$ and read at $\lambda=550 \mathrm{~nm}$.

Total and differential cell counts: Total and differential blood cell counts were carried out, because not all haemocyte sub-populations are phagocytic, nor do all release reactive $\mathrm{O}_{2}$ metabolites (Pipe et al. 1995). The number of haemocytes per $\mathrm{ml}$ of undiluted haemolymph was counted on the fixed samples using an improved Neubauer haemocytometer (Wootton \& Pipe 2003). To determine the proportion of eosinophil and basophil cell types, haemolymph cells were stained on prepared slides (Wootton \& Pipe 2003) for determination of eosinophils; the remaining haemocyte population was assumed to be basophilic. A fixed volume of haemolymph $(0.25 \mathrm{ml})$ was centrifuged $(150 \times g, 5 \mathrm{~min}$; Shandon UK Cytospin 3) onto a glass slide and the resultant cell monolayer post-fixed in $100 \%$ methanol for $160 \mathrm{~s}$, stained with Wright's stain (diluted 1:7 with $0.05 \mathrm{M}$ TBS, adjusted to $\mathrm{pH}$ 7.6) for $90 \mathrm{~s}$, rinsed in tap water, air dried and mounted in DPX mountant. Relative numbers of eosinophils and basophils were calculated after counting 200 haemolymph cells from each mussel (Parry \& Pipe 2004).

Statistical analyses. All statistical analyses were carried out using MINITAB 15. Data were tested for heterogeneity of variance using Levene's test. Normality was checked by plotting sample means against sample variances. When significant heterogeneity was 
detected, data were appropriately transformed, after which a general linear model (GLM) 2-way ANOVA was used to investigate the effects of $\mathrm{pH}$ and Time on each parameter. Where the GLM analysis identified a significant effect of Time, the effect of $\mathrm{pH}$ at each sampling interval was examined separately. To test for significant relationships between $\mathrm{pH}$ and the selected variable at each time interval, 3 different relationship models $\left(\mathrm{H}_{0}\right)$ were compared to a model of no relationship $\left(\mathrm{H}_{1}\right)$. These models were:

$\mathrm{H}_{1}: y=\mu$ (no relationship, i.e. one single mean, fits 1 parameter)

$\mathrm{H}_{0}: y=\alpha_{1}+\beta x$ (linear relationship, fits 2 parameters)

$\mathrm{H}_{0}: y=\alpha_{1}+\beta x+\gamma x^{2}$ (quadratic relationship, fits 3 parameters)

$\mathrm{H}_{0}: y_{1}=\mu_{1} ; y_{2}=\mu_{2} ; y_{3}=\mu_{3} ; y_{4}=\mu_{4}$ (4 independent means, i.e. ANOVA relationship, fits 4 parameters)

The F-ratio was calculated using:

$$
F=\frac{\left(\mathrm{RSS}_{\mathrm{H}_{0}}-\mathrm{RSS}_{\mathrm{H}_{1}}\right) /(p-q)}{\mathrm{RSS}_{\mathrm{H}_{1}} /(n-p)}
$$

where RSS is the residual sum of squares from fitting the model, $p$ is the number of parameters fitted to $\mathrm{H}_{1}, q$ is the number of parameters fitted to $\mathrm{H}_{0}$ and $n$ is the number of sample points.

The $F$-ratio was compared to the distribution of $F$. If $F>F(5 \%), \mathrm{H}_{1}$ was rejected. If more than one significant model was identified, the best model was determined by comparing decreasingly unconstrained models $\left(\mathrm{H}_{0}\right)$ against a fully unconstrained model $\left(\mathrm{H}_{1}\right)$. These models were:

$\mathrm{H}_{1}: y_{1}=\mu_{1} ; y_{2}=\mu_{2} ; y_{3}=\mu_{3} ; y_{4}=\mu_{4}$ (4 independent means, fits 4 parameters)

$\mathrm{H}_{0}: y=\mu$ (no relationship, i.e. one single mean, fits 1 parameter)

$\mathrm{H}_{0}: y=\alpha_{1}+\beta x$ (linear relationship, fits 2 parameters)

$\mathrm{H}_{0}: y=\alpha_{1}+\beta x+\gamma x^{2}$ (quadratic relationship, fits 3 parameters)

Again, the F-ratio was calculated using Eq. (1) and compared to the distribution of $F$ and, if $F>F(5 \%), \mathrm{H}_{1}$ was rejected, i.e. the constrained model (no relationship, linear or quadratic) did not fit the data as well as the fully unconstrained model (ANOVA). The simplest constrained model that fitted the data, as well as the unconstrained model, were considered to be the most appropriate models.

Where GLM analysis identified a significant effect of $\mathrm{pH}$, the effect of Time was also examined separately, following the methods above. Where GLM analysis identified a significant effect of Time but not $\mathrm{pH}$, the data from the different $\mathrm{pH}$ treatments were pooled before a 1-way ANOVA analysis of Time vs. the variable was carried out. The models described above were used to determine the best-fit relationship between Time and the variable.

\section{RESULTS}

Data had sufficient homogeneity of variance for ANOVA, with exception of the NBT assay. NBT assay data had sufficient homogeneity of variance after transformation (+100; square root). There were no significant differences between mussel holding tanks in any treatment.

\section{Phagocytosis assay}

There were significant effects of both $\mathrm{pH}$ and Time on phagocytosis (Table 2, Fig. 1). Phagocytosis levels declined with decreasing $\mathrm{pH}$ on Days 16 and 32 (Table 3). Compared to Day 0 mussels, controls displayed an increase in phagocytosis of $>600 \%$ on Day 16 and $>800 \%$ on Day 32. (Fig. 2) Mussels in reduced $\mathrm{pH}$ treatments also increased their phagocytosis levels on Days 16 and 32, compared to previous days, but phagocytosis decreased after Day 16. No significant effect of $\mathrm{pH}$ was detected on Days 4 and 8 , but a significant quadratic relationship was seen for Day 2 (Table 3); the effect of Time on phagocytosis within each $\mathrm{pH}$ treatment was significant (Table 3). Consequently, the duration of exposure to reduced $\mathrm{pH}$ contributed to the phagocytosis levels observed.

Table 2. General linear model ANOVA for phagocytosis (number of zymosan particles phagocytosed per mg of haemolymph protein), superoxide dismutase (SOD) inhibitable superoxide produced per mg of haemolymph protein (NBT assay), total cell count per ml of haemolymph, and percentage of eosinophilic haemocytes within the haemolymph, against $\mathrm{pH}$ and

Time. Adj MS = adjusted mean square; ns: not significant

\begin{tabular}{|lcccc|}
\hline Source and Factor & $\mathrm{df}$ & Adj MS & $F$ & $\mathrm{p}$ \\
\hline Phagocytosis assay & & & & \\
$\mathrm{pH}$ & 1 & 1675037 & 99.58 & $<0.001$ \\
Time & 3 & 103931 & 6.18 & $<0.001$ \\
Error & 199 & 16821 & & \\
NBT assay & & & & \\
$\mathrm{pH}$ & 1 & 0.011966 & 1.20 & $\mathrm{~ns}$ \\
Time & 3 & 0.080530 & 8.09 & 0.005 \\
Error & 199 & 0.009953 & & \\
Total cell count & & & & \\
pH & 1 & $5.760 \times 10^{13}$ & 0.21 & $\mathrm{~ns}$ \\
Time & 3 & $3.761 \times 10^{12}$ & 3.28 & $\mathrm{~ns}$ \\
Error & 123 & $1.756 \times 10^{13}$ & & \\
Percentage of eosinophils & & & \\
$\quad \mathrm{pH}$ & 1 & 142.99 & 1.826 & $\mathrm{~ns}$ \\
Time & 3 & 1709.67 & 22.21 & $<0.001$ \\
Error & 123 & 76.99 & & \\
\hline
\end{tabular}



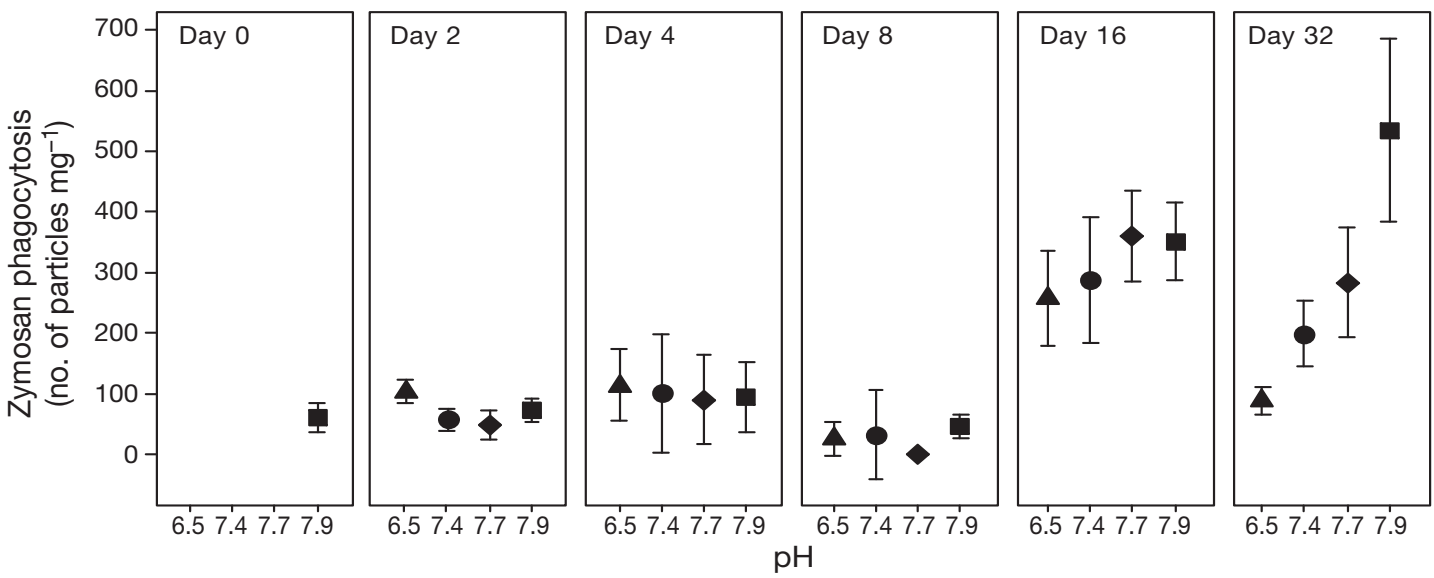

Fig. 1. Mytilus edulis. Number of phagocytosed zymosan particles (mean $\pm 95 \% \mathrm{CI}_{i} \mathrm{n}=10$ ) per mg of haemolymph protein

\section{NBT assay}

Time, but not $\mathrm{pH}$, affected the levels of intracellular superoxide anions $\left(\mathrm{O}_{2}^{-}\right)$produced in the haemocytes (Table 2). Therefore, $\mathrm{pH}$ data were pooled and the effect of Time was investigated. Overall, there was an increase in superoxide production with Time (Fig. 3), but this increase did not fit a linear or quadratic relationship (Table 4).

\section{Total and differential cell counts}

There was no significant effect of $\mathrm{pH}$ or Time on the number of circulating haemocytes (Table 2). The overall mean cell count $\pm 95 \%$ CI was $6.44 \times 10^{6} \pm 0.74 \times 10^{6}$ haemocytes per $\mathrm{ml}$ of undiluted haemolymph. Time, but not $\mathrm{pH}$, significantly affected the differential cell counts (Table 2). Therefore, $\mathrm{pH}$ data were pooled and the effect of Time investigated. An increase in the percentage of circulating eosinophilic cells occurred on

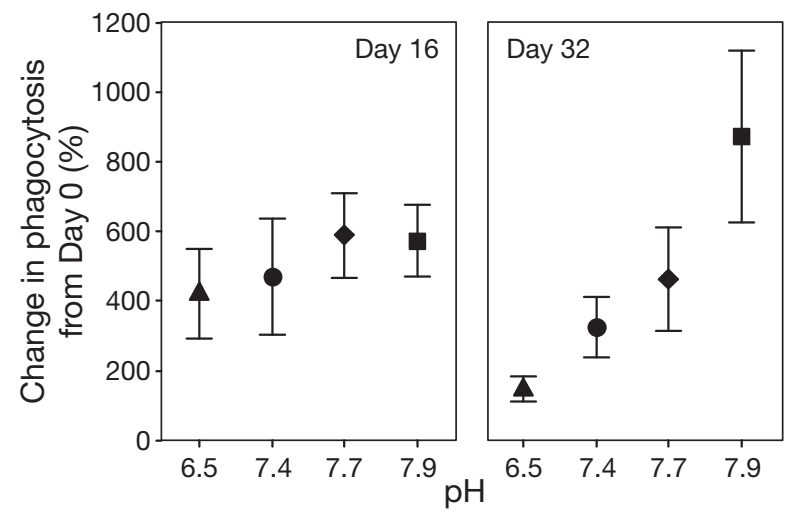

Fig. 2. Change (\%) in number of zymosan particles phagocytosed per mg of haemolymph protein for Days 16 and 32, compared to Day 0 (mean $\pm 95 \% \mathrm{CI}_{;} \mathrm{n}=10$ )

Days 16 and 32 (Fig. 4). The fraction of eosinophilic cells increased from 40 to $50 \%$ of the haemocyte population over the $32 \mathrm{~d}$ period. An ANOVA model, rather than a linear one was applicable (Table 4), due to a reduction on Day 8.

Table 3. Best fit relationship for effect of $\mathrm{pH}$ at each time period and effect of Time for each $\mathrm{pH}$ treatment for phagocytosis; values are $\mathrm{r}^{2}$ adjusted to account for number of predictors in the model. Bold: $\mathrm{H}_{0}$ rejected $(\mathrm{p}<0.05)$, i.e. constrained model did not fit the data as well as the fully unconstrained ANOVA model. Best model identified is the least constrained model not significantly different from the full ANOVA model

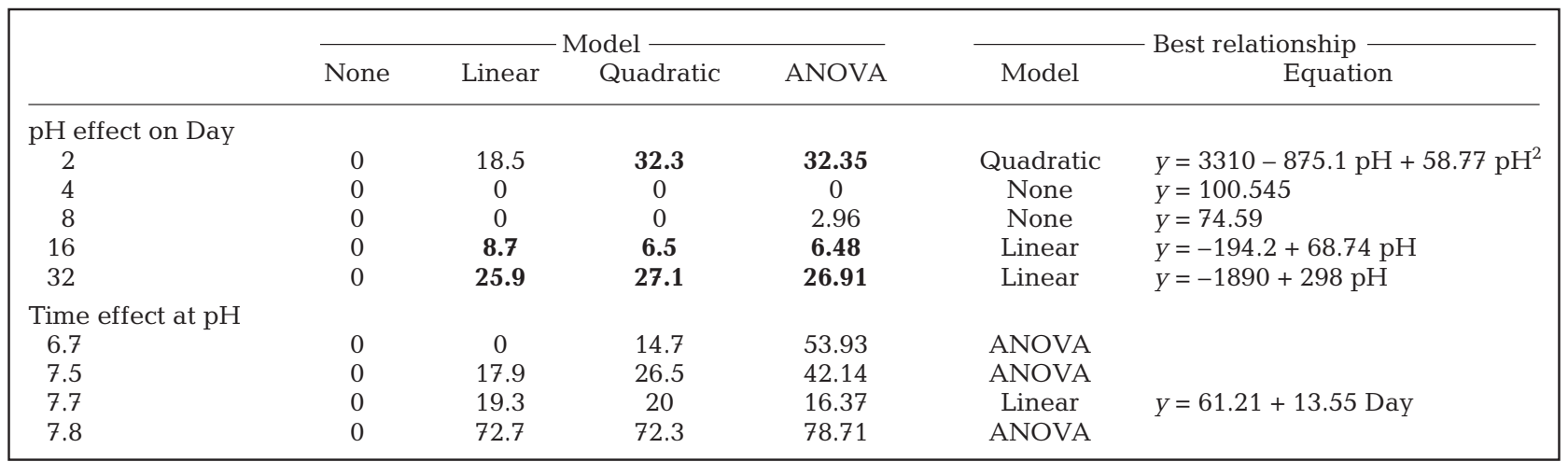




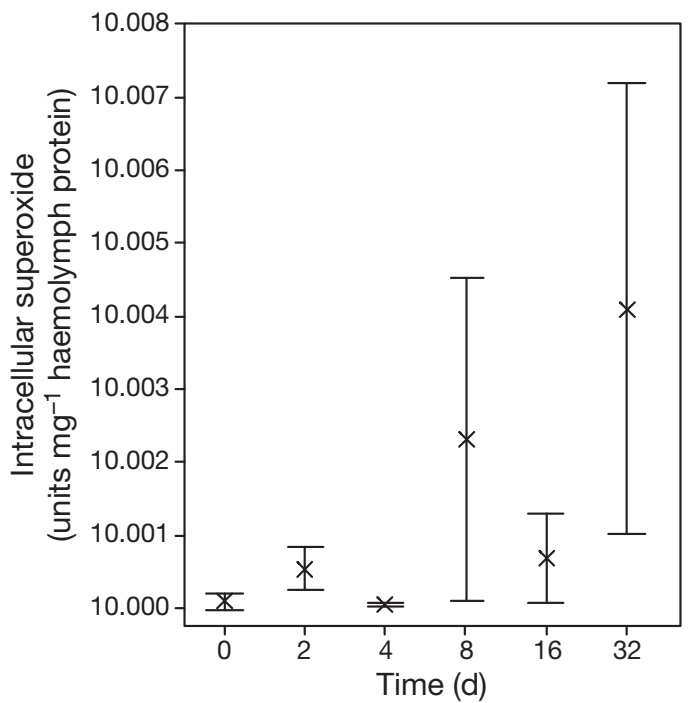

Fig. 3. Mytilus edulis. Effect of Time on levels of SOD inhibitable superoxide produced by the haemocytes (transformed data; mean $\pm 95 \%$ CI based on pooled data for $\mathrm{pH}$ treatments; $\mathrm{n}=40$ )

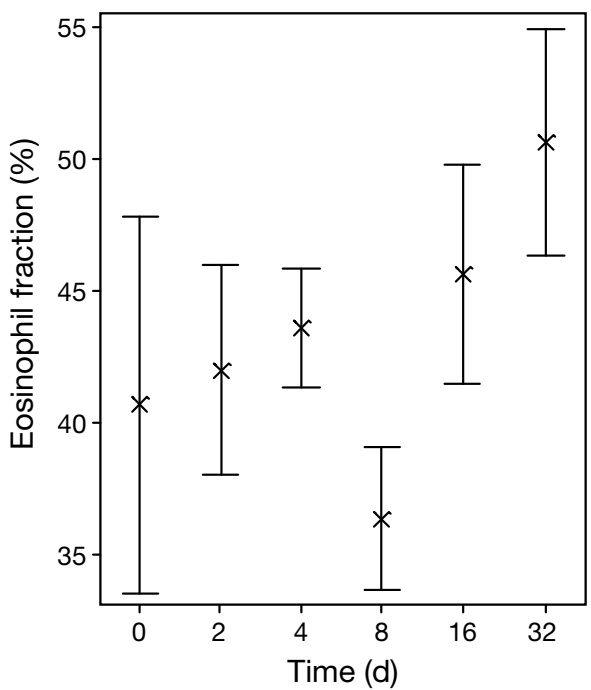

Fig. 4. Mytilus edulis. Effect of Time on the percentage of circulating eosinophilic haemocytes (mean $\pm 95 \%$ CI based on pooled $\mathrm{pH}$ treatments; $\mathrm{n}=6$ )

\section{DISCUSSION}

This is first evidence that medium term (32 d) exposure to elevated $\mathrm{CO}_{2}$ levels disrupts the ability of Mytilus edulis to express an immune response by suppressing levels of phagocytosis. Phagocytosis exhibited a strong decline as a function of decreasing $\mathrm{pH}$ (increasing $\mathrm{CO}_{2}$ ) on Days 16 and 32. Continued uptake of $\mathrm{CO}_{2}$ by the oceans may have progressively adverse effects on the immune function in mussels, with both ecological and commercial consequences. Whilst the current study does not identify the mechanism by which acidification causes suppression of the immune response, evidence from previous studies suggests that it is due to elevated calcium ion $\left(\mathrm{Ca}^{2+}\right)$ concentrations in the haemolymph.

Increased $\mathrm{Ca}^{2+}$ concentrations in association with increased haemolymph $\mathrm{pCO}_{2}$ and decreased haemolymph $\mathrm{pH}$ occur in intertidal mussels during periods of shell closure (Lindinger et al. 1984). As mussels initially maintain a constant internal $\mathrm{pH}$ by decreasing their metabolic rates and/or dissolving their calcium carbonate shell (Gazeau et al. 2007) when exposed to elevated $\mathrm{CO}_{2}$ levels, it is likely that increased $\mathrm{Ca}^{2+}$ concentrations in the haemolymph are caused by shell dissolution. Tissue acidosis compensation via calcium carbonate shell dissolution (Crenshaw \& Neff 1969) and elevated $\mathrm{Ca}^{2+}$ concentrations in the haemolymph (Lindinger et al. 1984, Burnett 1997) have also been observed in other species of molluscs. Although shell dissolution was not directly investigated in the present study, mussel shells in the $\mathrm{pH} 6.7$ treatment did become thinner and more brittle.

The concentration of $\mathrm{Ca}^{2+}$ within intracellular vesicles or the cytosol is thought to act as an important messenger at the molecular level (Massullo et al. 2006), transmitting signals for regulating haemocyte functions such as cell spreading and phagocytosis (Humphries \& Yoshino 2003). If cellular disruptions were induced in mussels in the present study, this would explain the suppression of phagocytosis in response to decreasing levels of seawater $\mathrm{pH}$. Increasing seawater acidity significantly reduces lysosome health as measured by the Neutral Red Retention assay (D. Lowe unpubl. data). As lysosomes play an important role in the defence system, by storing hydrolytic enzymes involved in intracellular degradation (Winston et al. 1996), a reduction in lysosome health would contribute to the disruption of cellular pathways and increase in membrane fragility due to acidified seawater.

Exposure to acidified seawater could also alter the reproductive condition of the mussels, which in turn could affect rates of phago- 
cyctosis. Mussels expend energy for regulation in a variable and stressful environment, and growth and reproduction cannot be maximised. The energy invested in gametes and reproduction is accompanied by physiological costs that divert energy from reserves, possibly reducing adult survival rates, and stressful environmental conditions may cause delayed gamete release or gamete resorption (Stoeckmann \& Garton 2001). The stress of exposure to acidified seawater may have caused the mussels to resorb their gametes as a survival or energy saving strategy. Resorption of gametes would require the phagocytic haemocytes to be transferred to the mantle, whilst proliferation of haemocytes would keep the circulating cell counts constant, as observed here. The maturity of haemocytes is thought to affect cell function; large eosinophilic cells are more phagocytic than immature small cells (Cheng 1981). Consequently, the number of immature haemocytes circulating in mussels at low $\mathrm{pH}$ may have been greater, with reduced phagocytosis levels on Days 16 and 32. A previous experiment conducted under similar conditions found no evidence that acidified seawater affected gamete maturation (D. Lowe unpubl. data), and suppression of phagocytosis as a result of changes in reproductive condition is unlikely in the present study.

Mesocosms do not reproduce in situ conditions such as tidal regime or diet. This can lead to increased levels of stress for the animals. In the current study, mesocosm induced stress was probably responsible for the increase in phagocytosis seen in all mussels on Day 16 and in the controls on Day 32. Phagocytosis levels in the $\mathrm{pH}$ treatment mussels declined on Day 32, compared to Day 16, indicating that exposure to acidified sea water may hinder the ability of stressed mussels to express an immune response.

Increased stress can result in an increase in the number of circulating haemocytes in bivalves (Renwrantz 1990, Mayrand et al. 2005, Malagoli et al. 2007). As eosinophilic cells are largely responsible for phagocytosis and release of reactive oxygen metabolites (Pipe et al. 1997), it is assumed that an increase in immune response is directly related to the number and type of circulating cells. Here, total cell counts remained consistent and the percentage of circulating eosinophils only increased from 40 to $50 \%$. Therefore, the response in phagocytosis levels cannot be due solely to the slight increase in eosinophils, especially as there was no difference in eosinophil numbers between $\mathrm{pH}$ treatments. It is likely that the increase in levels of phagocytosis was partially due to changes in the activity and function of the haemocytes. In a $3 \mathrm{yr}$ study, Cao et al. (2007) found no change in the average number of circulating haemocytes between summer and winter months, although immune response altered significantly. They suggested that the seasonal difference in immune response was due to the physiological state and health of the haemocytes. It is possible that in the present study, stress due to the holding conditions caused the haemocytes to become more active, whilst the increase in seawater acidity reduced haemocyte health and function. This could explain why immune response was altered, while haemocyte counts remained stable for the duration of the experiment.

The present study has demonstrated that seawater acidification can have a significant impact on the immune systems of mussels. Although this study did not demonstrate the exact mechanisms for this effect, one possible explanation is that dissolution of the mussel shells resulted in elevated levels of $\mathrm{Ca}^{2+}$ in the haemolymph, which in turn affected on cellular metabolism, function and signalling pathways. There is a need for molecular research regarding the disruption that ocean acidification may have on cellular systems involved in immune response. In addition, long term studies are required to assess possible adaptation or recuperation of the immune system during continuous acidification stress.

Acknowledgements. We thank A. Beasley, C. Pascoe, H. Wood, H. Findlay, D. Lowe, K. R. Clarke and M. Jutson for their help. This study used the seawater acidification facility funded by the joint DEFRA/DTI project $\mathrm{IMCO}_{2}$ and the NERC standard grant (NE/C510016/1) awarded to S.W. This study is a contribution to the NERC funded program Oceans 2025 (Theme 3 - Coastal and shelf processes).

\section{LITERATURE CITED}

Berge JA, Bjerkeng B, Pettersen O, Schaanning MT, Oxnevad $S$ (2006) Effects of increased seawater concentrations of $\mathrm{CO}_{2}$ on the growth of the bivalve Mytilus edulis L. Chemosphere 62:681-687

Bibby R, Cleall-Harding P, Rundle S, Widdicombe S, Spicer J (2007) Ocean acidification disrupts induced defences in the intertidal gastropod Littorina littorea. Biol Lett 3: 699-701

Burnett LE (1997) The challenges of living in hypoxic and hypercapnic aquatic environments. Am Zool 37:633-640

Caldeira K, Wickett ME (2003) Anthropogenic carbon and ocean $\mathrm{pH}$. Nature 425:365

Cao A, Novás A, Ramos-Martinez JI, Barcia R (2007) Seasonal variations in haemocyte response in the mussel Mytilus galloprovincialis Lmk. Aquaculture 263:310-319

Cheng TC (1981) Bivalves. In: Ratcliffe NA, Rowley AF (eds) Invertebrate blood cells: general aspects, animals without true circulatory systems to cephalopods. Academic Press, London, p 233-300

Crenshaw MA, Neff JM (1969) Decalcification at the mantleshell interface in molluscs. Am Zool 9:881-889

Feely RA, Sabine CL, Lee K, Berelson W, Kleypas J, Fabry VJ, Millero FJ (2004) Impact of anthropogenic $\mathrm{CO}_{2}$ on the $\mathrm{CaCO}_{3}$ system in the oceans. Science 305:362-366

Gazeau F, Quiblier C, Jansen J, Gattuso JP, Middleburg J, 
Heip C (2007) Impact of elevated $\mathrm{CO}_{2}$ on shellfish calcification. Geophys Res Lett 34:L07603

Hawkins DG (2004) No exit: thinking about leakage from geologic carbon storage sites. Energy 29:1571-1578

Holloway S (2005) Underground sequestration of carbon dioxide-a viable greenhouse gas mitigation option. Energy 30:2318-2333

Humphries JE, Yoshino TP (2003) Cellular receptors and signal transduction in molluscan hemocytes: connections with the innate immune system of vertebrates. Integr Comp Biol 43:305-312

Ishimatsu A, Kikkawa T, Hayashi M, Lee K, Kita J (2004) Effects of $\mathrm{CO}_{2}$ on marine fish: larvae and adults. J Oceanogr 60:731-741

Kikkawa T, Kita J, Ishimatsu A (2004) Comparison of the lethal effect of $\mathrm{CO}_{2}$ and acidification on red sea bream (Pagrus major) during early developmental stages. Mar Pollut Bull 48:108-110

Koller LD (1990) Immunotoxicology: functional changes. In: Dayton AD (ed) Immunotoxicology of metals and immunotoxicology. Plenum Press, New York, p 233-284

Lindinger M, Lauren D, McDonald D (1984) Acid-base balance in the sea mussel, Mytilus edulis. Effects of environmental hypercapnia on intra- and extracellular acid-base balance. Mar Biol Lett 5:371-381

Malagoli D, Casarini L, Sacchi S, Ottaviani E (2007) Stress and immune response in the mussel Mytilus galloprovincialis. Fish Shellfish Immunol 23:171-177

Massullo P, Sumoza-Toledo A, Bhagat H, Partida-Sánchez S (2006) TRPM channels, calcium and redox sensors during innate immune responses. Semin Cell Dev Biol 17:654-666

Mayrand E, St-Jean S, Courtenay S (2005) Haemocyte response of blue mussels (Mytilus edulis L.) transferred from a contaminated site to a reference site: Can the immune system recuperate? Aquacult Res 36:962-971

Michaelidis B, Ouzounis C, Paleras A, Pörtner HO (2005) Effects of long-term moderate hypercapnia on acid-base balance and growth rate in marine mussels Mytilus galloprovincialis. Mar Ecol Prog Ser 293:109-118

Nagarajan R, Lea S, Goss-Custard JD (2006) Seasonal variations in mussel, Mytlius edulis L. shell thickness and strength and their ecological implications. J Exp Mar Biol Ecol 339:241-250

Orr JC, Fabry VJ, Aumont O, Bopp L and others (2005) Anthropogenic ocean acidification over the twenty-first century and its impact on calcifying organisms. Nature 437:681-686

Parry HE, Pipe RK (2004) Interactive effects of temperature and copper on immunocompetence and disease susceptibility in mussels (Mytilus edulis). Aquat Toxicol 69:311-325

Editorial responsibility: Peter Beninger, Nantes, France
Petes LE, Menge BA, Murphy GD (2007) Environmental stress decreases survival, growth, and reproduction in New Zealand mussels. J Exp Mar Biol Ecol 351:83-91

Pipe RK, Coles JA (1995) Environmental contaminants influencing immune function in marine bivalve molluscs. Fish Shellfish Immunol 5:581-595

Pipe RK, Coles JA, Farley SR (1995) Assays for measuring immune response in the mussel Mytilus edulis. In: Stolen JS, Fletcher TC, Smith SA, Zelikoff JT and others (eds) Techniques in fish immunology. Immunology and pathology of aquatic invertebrates, Vol. 4. SOS Publications, Fair Haven, NJ, p 93-100

Pipe RK, Coles JA, Farley SR (1997) The separation and characterisation of haemocytes from the mussel Mytilus edulis. Cell Tissue Res 289:537-545

Pörtner HO, Langenbuch M, Reipschläger A (2004) Biological impact of elevated ocean $\mathrm{CO}_{2}$ concentrations: lessons from animal physiology and earth history. J Oceanogr 60: 705-718

Raven J, Caldeira K, Elderfield H, Hoegh-Guldberg O and others (2005) Ocean acidification due to increasing atmospheric carbon dioxide. Royal Society Policy Doc 12/05, Clyvedon Press, Cardiff

Renwrantz L (1990) Internal defence system of Mytilus edulis. In: Stefano GB (ed) Studies in neuroscience: neurobiology of Mytilus edulis. Manchester University Press, Manchester, p 256-275

Riebesell U, Zondervan I, Rost B, Tortell PD, Zeebe RE, Morel FM (2000) Reduced calcification of marine plankton in response to increased atmospheric $\mathrm{CO}_{2}$. Nature 407: 364-367

Sabine CL, Feely RA, Gruber N, Key RM and others (2004) The oceanic sink for anthropogenic $\mathrm{CO}_{2}$. Science 305: 367-371

Stoeckmann AM, Garton DW (2001) Flexible energy allocation in zebra mussels (Dreissena polymorpha) in response to different environmental conditions. J N Am Benthol Soc 20:486-500

Widdicombe $\mathrm{S}$, Needham HR (2007) Impact of $\mathrm{CO}_{2}$-induced seawater acidification on the burrowing activity of Nereis virens and sediment nutrient flux. Mar Ecol Prog Ser 341: $111-122$

Winston GW, Moore MN, Kirchin MA, Soverchia C (1996) Production of reactive oxygen species by haemocytes from the marine mussel, Mytilus edulis: lysosomal localisation and the effect of xenobiotics. Comp Biochem Physiol 113C: 221-229

Wootton EC, Pipe RK (2003) Structural and functional characterisation of the blood cells of the bivalve mollusc, Scrobicularia plana. Fish Shellfish Immunol 15:249-262

Submitted: October 17, 2007; Accepted: February 22, 2008

Proofs received from author(s): March 16, 2008 